\title{
Cystic Duct
}

National Cancer Institute

\section{Source}

National Cancer Institute. Cystic Duct. NCI Thesaurus. Code C32421.

A short duct attached to the gallbladder through which the bile from the gallbladder is secreted in the common bile duct. 